\title{
POTENSI KANDUNGAN BIJI ANGGUR DALAM MEMPERCEPAT PENYEMBUHAN LUKA
}

\author{
Nadia Zulfa Firdaus, Asisther Avivo Alda, Ika Sari Gunawan \\ Fakultas Kedokteran, Universitas Lampung, Jl. Prof. Dr. Ir. Sumantri Brojonegoro No.1, Gedong \\ Meneng, Kec. Rajabasa, Kota Bandar Lampung, Lampung, Indonesia 35145 \\ *nzulfa123gmail.com $(+628127344005)$
}

\begin{abstract}
ABSTRAK
Luka adalah kondisi diskontinuitas skruktur anatomi jaringan tubuh mulai dari lapisan epitel kulit sampai lapisan jaringan subkutis, lemak, otot, tulang, serta struktur lain di sekitarnya seperti pembuluh darah, saraf, dan tendon akibat adanya trauma. Penyembuhan luka adalah proses dinamis yang meliputi unsur-unsur tubuh, pembuluh darah, fibroblast, dan sel epitel yang dirangkum dalam tiga fase utama yaitu fase inflamasi, fase proliferasi, dan fase maturasi. Biji anggur (Vitis vinifera L.) mengandung berbagai vitamin, karotenoid, senyawa polifenol, dan sterol yang menunjukkan efek menguntungkan pada penyembuhan luka. Tujuan dari tinjauan pustaka ini adalah untuk melaporkan temuan ilmiah terbaru tentang peran kandungan biji anggur dalam penyembuhan luka dengan sintesis kolagen, mencegah efek merusak dari radikal bebas, memastikan stabilitas dan integritas membran biologis, serta memproduksi kolagen yang mempercepat penyembuhan luka. Metode yang digunakan adalah metode literature searching melalui database NCBI dan Google Scholar. Tahun penerbitan sumber pustaka adalah dari tahun 2000 sampai tahun 2019 dengan 22 sumber pustaka. Tema yang dikumpulkan terkait dengan kandungan biji anggur terhadap penyembuhan luka. Hasil dari sintesis artikel yang telah ditemukan yaitu biji anggur bermanfaat dalam mempercepat penyembuhan luka.
\end{abstract}

Kata kunci: biji anggur, penyembuhan luka, polifenol

\section{THE POTENTION OF GRAPE SEED TOWARD ACCELERATE HEALING WOUND}

\begin{abstract}
Wound is condition of discontinue anatomical structure of the body's tissue from the epithelial layer of the skin to the subcutaneous tissue layer, fat, muscle, bone, and other surrounding structures such as blood vessels, nerves, and tendons due to trauma. Wound healing is a dynamic process involving the body, fibroblasts, and epithelial cells which are summarized in three main phases, namely the inflammatory phase, the proliferation phase, and the maturation phase. Grape seeds (Vitis vinifera L.) contain various vitamins, carotenoids, polyphenol compositions, and sterols which have beneficial effects on wound healing. The purpose of this literature evaluation is to report the latest scientific findings on the role of grape seeds in wound recovery by collagen synthesis, prevent damage to free radicals, ensure and integrate biological membranes, and produce collagen that can repair wounds. The method used in this article is literature seacrhing through the NCBI database and Google Scholar. The year of reaching the library source is from 2000 to 2019 with 22 library sources. The theme collected is related to grape seeds on wound healing. The results of the synthesis of articles that have been found are grape seeds that are beneficial in improving wound healing.
\end{abstract}

Keywords: grape seed, healing wound, pholiphenol 


\section{PENDAHULUAN}

Luka adalah kondisi diskontinuitas skruktur anatomi jaringan tubuh mulai dari lapisan epitel kulit sampai lapisan jaringan subkutis, lemak, otot, tulang, serta struktur lain di sekitarnya seperti pembuluh darah, saraf, dan tendon akibat adanya trauma (Velnar et al, 2009).

Pada penelitian yang dilakukan di Amerika, prevalensi luka adalah 3.50 per 1000 populasi penduduk. Mayoritas luka pada penduduk dunia yaitu luka karena pembedahan/trauma $(48.00 \%)$, ulkus kaki (28.00\%), luka dekubitus (21.00\%) (Diligence, 2009). Prevalensi luka di Indonesia tahun 2013 adalah $8.2 \%$, prevalensi tertinggi yaitu Sulawesi Selatan (12.8\%) dan terendah yaitu Jambi (4.5\%). Jenis luka yang paling sering dialami penduduk di Indonesia adalah luka lecet/memar (70.9\%) diikuti luka robek (23.2\%). Penyebab luka terbanyak disebabkan oleh jatuh (40.9\%), dan kecelakaan motor sebanyak (40.6\%) (Riskesdas, 2013).

Luka berdasarkan lama penyembuhannya dibagi menjadi dua, yaitu luka akut dan luka kronis. Luka akut biasa disebabkan oleh trauma dan bila mendapat penanganan segera maka penyembuhan sesuai dengan waktu yang diperkirakan sekitar 2 hingga 6 minggu. Sementara luka kronik adalah luka yang berlangsung lama, timbul berulang, atau terdapat gangguan pada proses penyembuhan sehingga penyembuhan luka gagal sembuh pada waktu yang diperkirankan yaitu lebih dari 6 minggu dan memiliki resiko tinggi untuk timbul kembali (Briant, 2007).

Terdapat faktor yang mempengaruhi penyembuhan luka meliputi faktor lokal dan faktor umum. Faktor luka terdiri dari oksigenasi yang penting terhadap kecepatan penyembuhan, pada daerah yang memiliki vaskularisasi baik luka dapat sembuh dengan cepat dan begitu pula sebaliknya, lalu ada tidaknya hematoma atau seroma yang dapat menghalangi proses penyembuhan luka dengan menambah jarak tepi luka dan jumlah debridemen yang diperlukan sebelum fibrosis terbentuk. Teknik operasi juga berpengaruh disebabkan penyembukan luka normal memerlukan keseimbangan antara lisis dan pembentukan kolagen. Sementara pada faktor umum, penyembuhan luka dipengaruhi oleh nutrisi terutama pada kekurangan vitamin $\mathrm{C}$, kekurangan seng terutama pada luka bakar, steroid yang dapat menghalangi lisis kolagen, sepsis, dan obat sitotoksik (Sabiston, 2011).

Perawatan luka dengan larutan povidone iodine $10 \%$ sampai saat ini masih banyak digunakan. Namun ternyata dapat menyebabkan iritasi, alergi, residu, toksik pada sel (Ismail, 2008). Oleh karena itu diperlukan terapi alternatif salah satunya dengan menggunakan biji anggur.

Anggur mengandung berbagai vitamin, karotenoid dan senyawa polifenol (Perestrelo et al., 2014). Ekstrak biji anggur merupakan sumber proanthocyanidins yang memiliki kekuatan antioksidan 20 kali lebih banyak dari vitamin $\mathrm{C}$ dan 50 kali lebih banyak dari vitamin E (Shi et al., 2003). Sehingga kandungan tersebut baik untuk membantu penyembuhan luka dengan meningkatkan neovaskularisasi lokal, remodeling matriks ekstraseluler, migrasi, dan diferensiasi sel fibroblastik (Velnar et al, 2009).

Tinjauan pustaka ini penting dilakukan untuk mengetahui kandungan biji 
anggur dan manfaatnya dalam mempercepat penyembuhan luka.

\section{METODE}

Metode yang digunakan dalam penulisan artikel ini adalah literature review. Sumber pustaka yang digunakan dalam artikel ini berjumlah 22 artikel pustaka baik yang berasal dari buku, jurnal nasional atau internasional, maupun website. Penelusuran sumber pustaka dalam artikel ini melalui database NCBI dan Google Scholar dengan kata kunci Grape Seed, Healing Wound, Polyphenol. Pemilihan artikel sumber pustaka dilakukan dengan melakukan peninjauan pada judul dan abstrak yaitu membahas tentang potensi buah cermai dalam mengatasi asma. Tahun penerbitan sumber pustaka dalam penulisan artikel ini adalah 2000 hingga tahun 2019.

\section{HASIL}

Biji anggur telah dilaporkan memiliki efek pencegahan yang baik terhadap kerusakan oksidatif pada DNA dan proanthocyanidins membantu melindungi tubuh terhadap kerusakan jaringan (Nassiri-Asl \& Hosseinzadeh, 2009). Proanthocyanidins adalah subtipe flavonoid dan sifat anti-oksidan dalam penyembuhan luka telah terbukti. Ekstrak biji anggur merupakan sumber proanthocyanidins, oleh karena itu menurut hasil uji klinis ini, kita mungkin dapat mengatakan bahwa proanthocyanidins yang ditemukan dalam biji anggur bersama dengan flavonoid lain, dapat memainkan bagian penting dalam proses penyembuhan luka kulit. Proanthocyanidins biji anggur memiliki kekuatan antioksidan 20 kali lebih banyak dari vitamin $C$ dan 50 kali lebih banyak dari vitamin E (Shi et al., 2003).
Uji klinis yang dilakukan oleh Hemmati et al, menunjukan setelah 3 hari perawatan, ukuran luka pada kelompok yang menerima ekstrak biji anggur jelas berkurang dibandingkan dengan kelompok plasebo. Pada hari ketujuh penelitian terlepas dari nonpenyembuhan dari seluruh kelompok plasebo, dalam kelompok yang menerima ekstrak biji anggur, 20 kasus dari $31(64,5 \%)$ telah pulih sepenuhnya dan hanya sedikit eritema yang terlihat jelas di lokasi luka (Hemmati et al., 2014).

Pada penelitian lain menyebutkan bahwa fenugreek, biji anggur, dan minyak wijen terbukti memiliki aktivitas yang lebih baik pada penyembuhan luka dibandingkan dengan obat Ciclafora karena ekstrak minyak sinergis dengan nilai kualitas, polifenol, klorofil, karoten, dan asam lemak yang dikandungnya (Moalla, 2016).

Alkaloid dan terpenoid dapat memberikan sifat astringen, antijamur atau antimikroba yang mungkin bermanfaat bagi perkembangan kaskade penyembuhan luka (Roy dan Saraf, 2006). Anthocyanin, leucoanthocyanin dan polifenol lainnya telah terbukti memiliki sifat antioksidan yang signifikan yang juga dapat bermanfaat dalam perkembangan penyembuhan luka (Nayak et al., 2009).

\section{PEMBAHASAN}

Luka adalah gangguan pada struktur, fungsi dan bentuk kulit normal yang dapat dibedakan menjadi 2 jenis menurut waktu penyembuhannya yaitu luka akut dan luka kronis (Granic \& Teot, 2012). 
Terdapat klasifikasi luka berdasarkan tingkat kontaminasinya, yaitu (Abdurrahmat, 2014):

1. Luka bersih (Clean wounds), yaitu luka bedah tak terinfeksi, tidak terjadi proses peradangan (inflamasi). Luka bersih biasanya menghasilkan luka yang tertutup. Kemungkinan terjadinya infeksi luka sekitar $1-5 \%$.

2. Luka bersih terkontaminasi (Cleancontamined wounds), merupakan luka pembedahan dimana saluran respirasi, pencernaan, genital atau perkemihan dalam kondisi terkontrol, kontaminasi tidak selalu terjadi. Kemungkinan timbulnya infeksi luka adalah 3-11\%.

3. Luka terkontaminasi (Contamined wounds), termasuk jenis luka terbuka, segar, luka akibat kecelakaan dan operasi dengan kerusakan besar dengan teknik aseptik atau terkontaminasi dari saluran cerna, pada kategori ini termasuk insisi akut, inflamasi nonpurulen. Kemungkinan infeksi luka $10-17 \%$

4. Luka kotor atau infeksi (Dirty wound), ialah jenis luka yang terjadi pada lingkungan yang sudah terkontaminasi oleh bakteri, termasuk juga luka akibat pelaksanaan operasi di tempat yang tidak steril, misalnya operasi darurat di lapangan. Kemungkinan terjadi infeksi lebih dari $27 \%$.

Penyembuhan luka adalah proses dinamis yang meliputi unsur-unsur tubuh, pembuluh darah, fibroblast, dan sel epitel. Mulanya, darah di dalam luka membeku, diikuti dengan respon peradangan, yang membersihkan sel mati dan bakteri. Fibroblast dan pembuluh darah meluas pada fibrin di bekuan darah, kolagen ditimbun dan setelah beberapa waktu, kolagen memperoleh kekuatan dari ikatan dan remodeling pada arah stres utama. Epitelisasi terjadi sangat cepat, untuk melindungi luka dari kontaminasi luar (Sabiston, 2011).

Penyembuhan luka dibagi menjadi penyembuhan primer dan sekunder. Umumnya penyembuhan luka merupakan serangkaian proses yaitu induksi respon peradangan akut oleh jejas, regenerasi sel parenkim, migrasi dan proliferasi baik parenkim maupun jaringan ikat, sintesis protein, dan remodelling baik parenkim untuk mengembalikan fungsi jaringan maupun jaringan ikat untuk memperoleh kekuatan luka. Perbedaan antara penyembuhan primer dan sekunder adalah jika kehilangan sel atau jaringan lebih luas maka proses penyembuhan menjadi kompleks, regenerasi sel parenkim tidak dapat mengembalikan bentuk asal sehingga terbentuk granulasi kemudian jaringan parut (Abbas et al., 2015).

Adapun fase penyembuhan luka dibagi menjadi 3, yaitu (Abbas et al., 2015)

1. Fase Inflamasi

Dimulai setelah terjadi luka dan berakhir 3-4 hari. Terjadi hemostasis dan fagositosis . setelah luka, terjadi vasokontriksi yang menyebabkan terjadi pembekuan darah untuk menutupi luka. Setelah itu terjadi vasodilatasi untuk meningkatkan aliran darah dan sel darah putih ke daerah luka dan menghancurkan bakteri. Lalu sel makrofag masuk dan mengeluarkan faktor angiogenesis untuk merangsang pembentukan epitel.

2. Fase Proliferasi

Dimulai hari ke 3-4 hingga hari ke 21. Fibroblas menyintesis kolagen dan substansi dasar. Lapisan dari sel 
epitel melintasi luka dan aliran darah yang disebut granulasi.

3. Fase Maturasi

Dimulai pada hari ke 21 hingga luka sembuh sempurna. Kolagen baru menyatu menekan pembuluh darah dalam luka sehingga bekas menjadi rata dan tipis.

Luka dapat mengalami komplikasi pada proses penyembuhannya meliputi infeksi yaitu invansi mikroorganisme dapat berupa bakteri pada saat trauma, pembedahan, maupun setelah pembedahan. Gejalanya yaitu nyeri, peningkatan suhu, bengkak, kemerahan, peningkatan sel darah putih, dan purulen. Lalu dehisen atau terpisahnya lapisan luka secara parsial atau total. Dehisen sering terjadi pada luka pembedahan abdomen dan terjadi setelah regangan mendadak, misalnya batuk, muntah atau duduk tegak di tempat tidur. Dapat pula terjadi eviserasi yaitu terpisahnya lapisan luka secara total dapat menimbulkan eviserasi (keluarnya organ viseral melalui luka yang terbuka). Kemudian Fistul, terbentuknya saluran abnormal yang berada diantara dua buah organ atau diantara organ dan bagian luar tubuh. (Potter dan Perry, 2006).

Perawatan luka dengan larutan povidone iodine $10 \%$ sampai saat ini masih banyak digunakan. Larutan ini cocok untuk luka kotor atau terinfeksi oleh bakteri gram positif maupun gram negatif, spora, jamur, dan protozoa. Namun ternyata dapat menyebabkan iritasi, alergi, residu, toksik pada sel (Ismail, 2008). Oleh karena itu diperlukan terapi alternatif salah satunya dengan menggunakan biji anggur.

Anggur (Vitis vinifera L) merupakan perdu merambat yang termasuk ke dalam keluarga Vitaceae. Di antara keluarga ini, spesies dari genus Vitis ditemukan terutama di zona beriklim belahan bumi utara yang didistribusikan antara Amerika Utara dan Asia Timur. $V$. vinifera adalah satu-satunya spesies Vitis yang terbukti berasal dari Eropa (Joao, 2019).

Tumbuhan anggur berbentuk semak, berumur panjang, tinggi mencapai 8 meter. Akar tunggang, batang berkayu bentuk silindris, menjalar, berwarna hijau kecoklatan, dan memiliki permukaan yang halus. Daunnya tunggal tersusun berseling,warna hijau, bentuk bundar hingga jorong dengan panjang 10-16 cm, lebar 8-14 cm. Helai daun tipis, pangkal berlekuk, tepi runcing, permukaan berbulu. Bunga majemuk dan muncul pada ketiak daun, kelopak berbentuk mangkuk berwarna hijau. Buah termasuk dalam kategori buni, bulat atau lonjong, panjang 2-3 $\mathrm{cm}$, berwarna hijau, ungu, atau hitam. Biji berbentuk lonjang berwarna coklat (Jumanta, 2019).

Anggur mengandung berbagai vitamin, karotenoid dan senyawa polifenol (Perestrelo et al., 2014) Polifenol adalah metabolit tanaman sekunder yang umumnya dibagi menjadi dua kelompok: non-flavonoid (asam hidroksibenzoat, asam hidroksisinamat, dan stilbena) dan senyawa flavonoid (anthocyanin, flavonol, dan flavan-3ols). Dalam buah anggur, asam hidroksibenzoat, stilbena, flavonol, dan antosianin terutama terletak di kulit sedangkan asam hidroksisinamatik terutama terletak di daging buah, dan flavan-3-ols dalam biji (Aubert dan Chalot, 2018 Senyawa polifenol dalam produk memainkan peran penting untuk efek antioksidan, antiinflamasi dan antimikroba (Shi et al., 2003). 
Anggur juga mengandung karotenoid, terutama betacarotene dan lutein. Xantofil lain seperti neoxanthin, violaxanthin, atau lutein-5,6-epoksida juga ada tetapi pada konsentrasi yang lebih rendah (Mendes-Pinto, Ferreira, Oliveira, \& Guedes de Pinho, 2004). Anggur juga merupakan sumber vitamin $\mathrm{C}$ dan $\mathrm{E}$. Vitamin $\mathrm{C}$ umumnya dianggap sebagai vitamin paling penting untuk nutrisi manusia dan antioksidan alami yang penting (Lee \& Kader, 2000). Vitamin E terdiri dari empat tokoferol dan tokotrienol yang sesuai. Alfatokoferol umumnya dikenal sebagai bentuk vitamin $\mathrm{E}$ paling aktif pada manusia. Dalam anggur, tokoferol didistribusikan secara homogen di semua jaringan (pericarp, mesocarp, dan biji-bijian) dan bentuk alfa umumnya dominan. Dalam Vitis vinifera L., tokotrienol hanya ada dalam biji (Horvath et al., 2006).

Dilaporkan dalam Database Komposisi Makanan USDA di mana vitamin $\mathrm{C}$ atau asam askorbat diindikasikan sebagai $3,2 \mathrm{mg} / 100 \mathrm{~g}$ untuk anggur merah atau hijau (USDA, 2017). Total kandungan vitamin $\mathrm{E}$ bervariasi antara 5,0 dan $8,1 \mathrm{mg} / \mathrm{kg}$. Lutein dan betacarotene adalah karotenoid paling umum dalam anggur, mewakili hampir $85 \%$ dari total karotenoid, hanya dua senyawa yang diukur dalam penelitian ini (Mendes Pinto et al., 2004). Lutein dominan di semua kultivar (61-72\%) dan bervariasi antara 0,9 dan 2,0 $\mathrm{mg} / \mathrm{kgFW}$, sedangkan betacarotene berkisar antara 0,6 hingga $1,0 \mathrm{mg} / \mathrm{kgFW}$ (Aubert dan Chalot, 2018).

Polifenol dan karotenoid bersama dengan vitamin $\mathrm{E}$ dan sterol menunjukkan efek yang menguntungkan pada penyembuhan luka dan sintesis kolagen dengan mencegah efek merusak dari radikal bebas dan memastikan stabilitas dan integritas membran biologis. Selain itu, sterol adalah senyawa kuat yang dapat membantu mengurangi peradangan sistemik. Mereka dapat mempercepat pertumbuhan kulit baru dengan merangsang makrofag dan meningkatkan produksi fibroblast dan kolagen (De Jong et al., 2008).

Asam lemak tak jenuh ganda termasuk asam oleat, asam linoleat, dan asam linolenat pada ekstrak minyak biji anggur merupakan prekursor asam arakidonat, penting dalam kaskade inflamasi (prostaglandin, tromboksan, dan leukotrien) (Fetterman dan Zdanowicz, 2009). Zat ini bertindak sebagai mediator inflamasi dan mempercepat proses inflamasi. Dengan demikian, mereka meningkatkan neovaskularisasi lokal, remodeling matriks ekstraseluler, migrasi, dan diferensiasi sel fibroblastik yang mempercepat penyembuhan luka (Velnar et al, 2009).

Singkatnya, biji anggur (Vitis vinifera L.) mengandung berbagai vitamin, karotenoid dan senyawa polifenol. Polifenol dan karotenoid bersama dengan vitamin $\mathrm{E}$ dan sterol menunjukkan efek yang menguntungkan pada penyembuhan luka dan sintesis kolagen dengan mencegah efek merusak dari radikal bebas dan memastikan stabilitas dan integritas membran biologis. Selain itu, sterol adalah senyawa kuat yang dapat membantu mengurangi peradangan sistemik. Mereka dapat mempercepat pertumbuhan kulit baru dengan merangsang makrofag dan meningkatkan produksi fibroblast dan kolagen. 


\section{SIMPULAN}

Biji anggur bermanfaat dikarenakan biji anggur mengandung polifenol, karotenoid, vitamin E, sterol, dan senyawa lain yang baik dalam membantu mempercepat proses penyembuhan luka.

\section{DAFTAR PUSTAKA}

Aubert, C., \& Chalot, G. (2018). Chemical composition, bioactive compounds, and volatiles of six table grape varieties ( Vitis vinifera L.). Food Chemistry, 240, 524-533.

Abbas, A.K., Aster, J.C., dan Kumar, V. (2015). Buku Ajar Patologi Robbins. Edisi 9. Singapura: Elsevier Saunders.

De Jong A., Plat J., A. Bast, R. W. L. Godschalk, S. Basu, and R. P. Mensink. (2008). Effects of plant sterol and stanol ester consumption on lipid metabolism, antioxidant status and markers of oxidative stress, endothelial function and low-grade inflammation in patients on current statin treatment. European Journal of Clinical Nutrition, vol. 62 , no. 2, pp. 263-273.

Fetterman J. W. Jr. and Zdanowicz M. M. (2009). Therapeutic potential of n-3 polyunsaturated fatty acids in disease. American Journal of Health-System Pharmacy, vol. 66, no. 13 , pp. 1169- 1179

Granick, M.S., \& Teot, L. (2012). Surgical Wound Healing and Management, ed. 2. USA : Informa Healthcare

Hemmati, A. A., Foroozan, M., Houshmand, G., Moosavi, Z. B., Bahadoram, M., \& Maram, N. S.
(2014). The Topical Effect of Grape Seed Extract 2\% Cream on Surgery Wound Healing. Global Journal of Health Science, 7(3).

Horvath, G., Wessjohann, L., Bigirimana, J., Monica, H., Jansen, M., Guisez, Y., Horemans, N. (2006). Accumulation of tocopherols and tocotrienols during seed development of grape (Vitis vinifera L. cv. Albert Lavallée). Plant Physiology and Biochemistry, 44(11), 724-731.

João L. C., Helena G. S, Miguel J.N. R, Jorge C, José ED, Sara A, et al. (2019). Vitis flower types: from the wild to crop plants. Journal Plant Biology. PubMed 31737441

Jumanta. (2019). Buku pintar tumbuhan; segala yang perlu kita tahu tentang kehidupan mereka. Elex Media Komputindo; Jakarta. p34

Lee, S. K., \& Kader, A. A. (2000). Preharvest and postharvest factors influencing vitamin $\mathrm{C}$ content of horticultural crops. Postharvest Biology and Technology, 20(3), 207-220.

Mendes-Pinto, M. M., Ferreira, A. S., Oliveira, M. B. P., \& Guedes de Pinho, P. 2004. Evaluation of some carotenoids in grapes by reversed-and normal-phase liquid chromatography: A qualitative analysis. Journal of Agricultural and Food Chemistry, 52(10), 3182-3188.

Moalla Rekik, D., Ben Khedir, S., Ksouda Moalla, K., Kammoun, N. G., Rebai, T., \& Sahnoun, Z. 
(2016). Evaluation of Wound Healing Properties of Grape Seed, Sesame, and Fenugreek Oils. Evidence-Based Complementary and Alternative Medicine, 2016, $1-12$.

Nassiri-Asl, M., \& Hosseinzadeh, H. (2009). Review of the pharmacological effects of Vitis vinifera (Grape) and its bioactive compounds. Phytother Res, 23(9), 1197-1204

Nayak, B. S., Ramdath, D. D., Marshall, J. R., Isitor, G. N., Eversley, M., Xue, S., \& Shi, J. (2009). Woundhealing activity of the skin of the common grape (Vitis Vinifera) variant, cabernet sauvignon. Phytotherapy Research, n/a-n/a

Perestrelo, R., Silva, C., Pereira, J., \& Câmara, J. S. (2014). Healthy Effects of Bioactive Metabolites from Vitis vinifera L. Grapes: A Review. In Grapes: Production, Phenolic Composition and Potential Biomedical Effects (Nova Science Technology, pp. 305-338). José S. Câmara.

Potter A \& Perry AG. (2006). Buku Ajar Fundamental Keperawatan: Konsep, Proses, dan Praktik. 4th ed. EGC: Jakarta.

Roy A, Saraf S. (2006). Limonoids: overview of significant bioactive triterpenes distributed in plant kingdom. Biol Pharm Bull 29: 191-201.

RISKESDAS. (2013). Riset Kesehatan Dasar. Departemen Kesehatan.

Sabiston C. D. (2011). Buku Ajar Bedah Sabiston (alih bahasa : Andrianto P \&Timan I.S). Jakarta: Buku Kedokteran EGC.

Shi J, Yu J, Pohorly JE, Kakuda Y. (2003). Polyphenolics in grape seeds - biochemistry and functionality. J Med Food 6: 291299.

USDA. (2017). USDA Food Composition Databases. https://ndb.nal.usda.gov/ndb/nutri ents/index.

Velnar T, Bailey T,Smrkolj V. (2009). The wound healing process; an overview of cellular and molecular mechanism. The $\mathrm{J}$ of International Medical Research p1528-42 